\title{
The Sclerotinia sclerotiorum pac1 Gene Is Required for Sclerotial Development and Virulence
}

\author{
Jeffrey A. Rollins \\ Department of Plant Pathology, 1453 Fifield Hall, University of Florida, Gainesville, FL 32611-0680 U.S.A.
}

Submitted 9 January 2003. Accepted 2 June 2003.

\begin{abstract}
The synergistic activities of oxalic acid and endopolygalacturonases are thought to be essential for full virulence of Sclerotinia sclerotiorum and other oxalate-producing plant pathogens. Both oxalic acid production and endopolygalacturonase activity are regulated by ambient $\mathrm{pH}$. Since many gene products with $\mathrm{pH}$-sensitive activities are regulated by the PacC transcription factor in Aspergillus nidulans, we functionally characterized a pacC gene homolog, pac1, from $S$. sclerotiorum. Mutants with loss-of-function alleles of the pac1 locus were created by targeted gene replacement. In vitro mycelial growth of these pac1 mutants was normal at acidic $\mathbf{p H}$, but growth was inhibited as culture medium pH was increased. Development and maturation of sclerotia in culture was also aberrant in these pac1 replacement mutants. Although oxalic acid production remained alkaline pH-responsive, the kinetics and magnitude of oxalate accumulation were dramatically altered. Additionally, maximal accumulation of endopolygalacturonase gene transcripts (pg1) was shifted to higher ambient $\mathrm{pH}$. Virulence in loss-of-function pac1 mutants was dramatically reduced in infection assays with tomato and Arabidopsis. Based on these results, pac1 appears to be necessary for the appropriate regulation of physiological processes important for pathogenesis and development of S. sclerotiorum.
\end{abstract}

Additional keyword: pathogenicity.

Sclerotinia sclerotiorum, an aggressive phytopathogen, is capable of causing disease on at least 408 described species of plants from 278 genera in 75 families (Boland and Hall 1994). The majority of these hosts are dicotolydenous, although a number of agriculturally significant monocotyledonous plants are also hosts. The limited tissue specificity and spreading necrosis associated with Sclerotinia diseases suggests nonspecific mechanisms of pathogenicity. The physiological factors that have been attributed to pathogenicity, oxalic acid and polygalacturonase activity, are thought to function synergistically to depolymerize the polygalacturonic acid matrix that is a prominent structural and functional component of the cell walls of most Sclerotinia hosts (Carpita and Gibeaut 1993).

In oxalate-producing pathogens such as $S$. sclerotiorum, oxalic acid accumulates early during pathogenesis and increases in concentration as host colonization advances (Bateman 1964; Bateman and Beer 1965). Concomitant with the increase in oxalic acid is a decrease in extracellular host $\mathrm{pH}$ to 4 to 5 . Since the $\mathrm{pH}$ optima of extracellular enzymes produced by these oxalate-secreting fungi are generally below $\mathrm{pH}$ 5.0, the lowered

Corresponding author: J. Rollins; Telephone: (352) 392-3631; Fax: (352) 392-6532; E-mail: jarollins@ifas.ufl.edu.
$\mathrm{pH}$ of infected tissues enhances their activity (Bateman and Beer 1965; Magro et al. 1984; Maxwell and Lumsden 1970). The calcium from calcium pectate in the middle lamellae also is chelated by oxalic acid, allowing polygalacturonases to hydrolyze pectates more readily (Bateman and Beer 1965).

The importance of oxalic acid production and polygalacturonase synergy during colonization and symptom development in diseases caused by Sclerotinia spp. has been well established (Marciano et al. 1983; Maxwell and Lumsden 1970). Although a significant body of literature describing this physiological basis of $S$. sclerotiorum pathogenesis exists, the molecular regulators of these pathogenic processes have not been functionally investigated in this fungus. UV-induced mutants deficient in oxalic acid accumulation have been demonstrated to be nonpathogenic (Godoy et al. 1990). Although this finding further implicates important roles for oxalic acid during pathogenesis, targeted disruption of oxalate biosynthetic or pectolytic enzyme-encoding genes has not been accomplished in S. sclerotiorum. Although the synergism of diverse physiological factors may be required for broad host-range pathogenicity, these factors undoubtedly rely upon common environmental signals and molecular response pathways to coordinate their production and activities. The identification and understanding of these pathways may lead to novel targets for blocking disease development.

In addition to appropriately sensing the environment, S. sclerotiorum actively modifies its environment, making it acidic via oxalic acid secretion. An acidic host-pathogen environment provides a suitable condition for endopolygalacturonase activity and may also serve as a signal to enhance the production of this virulence factor and coordinate the production of new factors. An extensive list of cell-wall-degrading enzymes (CWDE) with low $\mathrm{pH}$ activities has been compiled from $S$. sclerotiorum (Lumsden 1979). One member of this group, an endopolygalacturonase encoded by the $p g l$ gene, is regulated by $\mathrm{pH}$ at the transcription level (Rollins and Dickman 2001). Accumulation of $p g 1$ transcripts is maximal between $\mathrm{pH} 3.0$ and 3.8 in vitro and decreases significantly above $\mathrm{pH}$ 4.2. This finding indicates a correlation between $\mathrm{pH}$-regulated gene transcription and catalytic activity of the encoded enzyme. The accumulation of oxalic acid itself is related to the $\mathrm{pH}$ and buffering capacity of the growth medium, such that higher levels of oxalate are produced at higher $\mathrm{pH}$ (Maxwell and Lumsden 1970). Oxalate production is self-limiting; as oxalic acid accumulates, $\mathrm{pH}$ decreases and limits further oxalic acid production. From these observations, a dynamic system of gene regulation based on ambient $\mathrm{pH}$ sensing and active modification of the ambient $\mathrm{pH}$ environment is suggested.

The Aspergillus nidulans model system has shown that the expression of genes encoding extracellular enzymes with differing $\mathrm{pH}$ optima are governed by an ambient $\mathrm{pH}$-sensing signal transduction pathway comprised of at least six pal gene 
products (Negrete-Urtasun et al. 1999). The regulated target of this pathway is the zinc finger transcription factor PacC (Tilburn et al. 1995). This pH-responsive gene-regulation system has been thoroughly reviewed recently (Peñalva and Arst 2002). Within this regulatory circuit, PacC is positively regulated under alkaline $\mathrm{pH}$ conditions to promote transcription of alkaline-expressed genes and simultaneously repress the expression of acid-expressed genes. The promoter regions of alkaline-expressed genes contain multiple copies of the $5^{\prime}$ GCCARG-3' consensus site that are recognized by $\mathrm{PacC}$ (Espeso et al. 1997). Under acidic ambient $\mathrm{pH}$ conditions, PacC is not activated, and the opposite pattern of transcriptional regulation is observed. This system of gene regulation ensures that enzymes with $\mathrm{pH}$-sensitive activity are produced under environmental $\mathrm{pH}$ conditions in which they can effectively function. Loss-of-function mutants of pacC produce a constitutive acid-expressing phenotype characterized by increased acid phosphatase and decreased alkaline phosphatase activities, decreased sensitivity to aminoglycoside antibiotics, increased sensitivity to molybdate, and lack of growth at alkaline pH (Arst et al. 1994; Caddick et al. 1986). Dominant activating mutations of pacC reverse these effects (Caddick et al. 1986; Espeso et al. 1993; Shah et al. 1991).

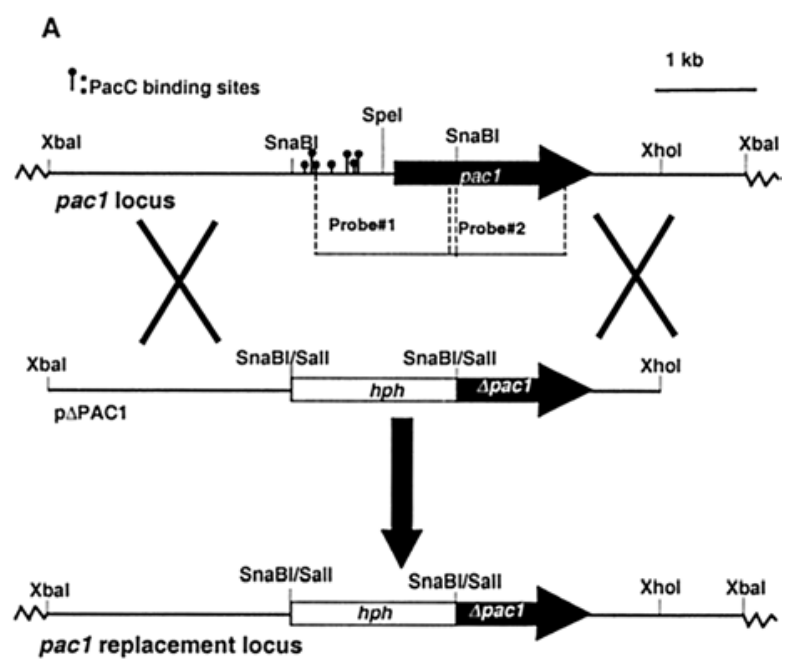

B

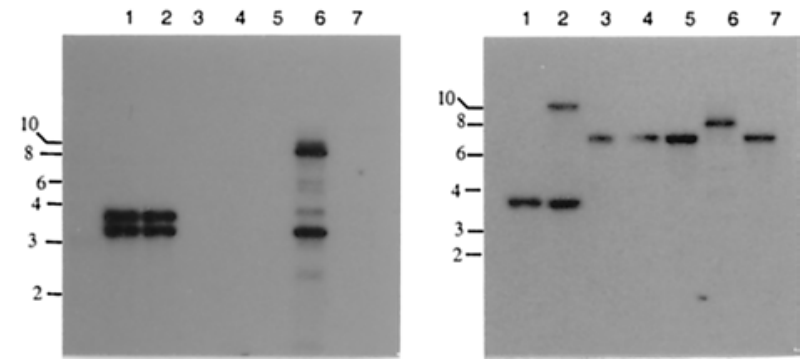

Fig. 1. Construction and analysis of pacl gene replacement transformants. A, pacl locus and gene-replacement construct containing the hygromycin phosphotransferase gene $(h p h)$ cassette in place of $1.6 \mathrm{~kb}$ of the pacl sequence between the SnaBI restriction enzyme sites. The double cross-over homologous recombination event resulting in a replacement of pacl sequences with the $h p h$ sequences is diagrammed. Locations of sequences used for hybridization probes are shown. B, Southern hybridization analysis of pacl gene replacement strains. Genomic DNAs from wild type (lane 1), ectopic strain Tpac1-9.1 (lane 2), gene-replacement strains Tpac1-7.2, Tpac1-1.2, and Tpac1-4.5 (lanes 3, 4, and 5, respectively), pac1-complemented strain Tpac1-4.1 (lane 6), and noncomplemented control strain Tpac1-2.2 (lane 7) were double digested with XbaI and SpeI. Left panel was hybridized with probe 1 sequences. Right panel was hybridized with probe 2 sequences.
Homologs of pacC have been isolated and characterized from ascomycete fungi closely related to A. nidulans, including A. niger and Penicillium chrysogenum (MacCabe et al. 1996; Suárez and Peñalva 1996), and from the cephalosporin-producing ascomycete, Acremonium chrysogenum (Schmitt et al. 2001). PacC homologs have also been characterized in a number of yeasts, including Saccharomyces cerevisiae ( $\mathrm{Su}$ and Mitchell 1993), in which it regulates entry into meiosis, sporulation, invasive growth, and alkaline adaptation (Futai et al. 1999; Su and Mitchell 1993), Yarrowia lipolytica (Lambert et al. 1997), in which it functions in $\mathrm{pH}$-dependent gene regulation, mating, and sporulation, and the opportunistic human pathogen Candida albicans, in which the pacC homolog RIM101/PRR2 (Wilson et al. 1999) is necessary for pH-regulated transcript accumulation, filamentous growth (Davis et al. 2000b), and full virulence (Davis et al. 2000a). In S. sclerotiorum, a pacC homolog, pac1, was previously identified, based on sequence homology and functional complementation of an A. nidulans pacC null strain (Rollins and Dickman 2001). To date, however, a pacC homolog has not been functionally characterized in any phytopathogenic fungus.

Ambient $\mathrm{pH}$ plays a definitive role in the in vitro regulation of the oxalic acid and endopolygalacturonase virulence factors in $S$. sclerotiorum. From these observations, we hypothesize that environmental $\mathrm{pH}$ dynamics during the host-pathogen interaction play a key role in regulating pathogenicity. Because $\mathrm{PacC}$ is central to the regulation of $\mathrm{pH}$-responsive genes in $A$. nidulans and other fungi, mutation of this gene in S. sclerotiorum may interfere with $\mathrm{pH}$-regulated gene expression required for the production of certain virulence factors. The goal of this study was to test this hypothesis by creating a loss-offunction pacl allele in S. sclerotiorum and characterizing the phenotypic effects of this mutation.

\section{RESULTS}

\section{Functional deletion of the pac1 locus.}

The strategy to replace the pacl locus with the pacl-hph gene-replacement construct described below is diagrammed in Figure 1A. Using this construct, approximately 70 hygromycin-resistant transformants were recovered and genetically purified by several rounds of hyphal-tip transfer. Genomic DNA from 16 of these transformants was double-digested with $X b a \mathrm{I}$ and SpeI and screened by Southern hybridization analysis, using the pacl sequences deleted from the gene-replacement vector as the hybridization probe (data not shown). Three transformants (Tpac1-1.2, Tpac1-4.5, and Tpac1-7.2) failed to hybridize with this probe.

Detailed Southern hybridization analysis of these three putative gene-replacement transformants, the wild-type recipient, and an additional randomly chosen transformant are shown in Figure 1B. Hybridization with probe 1 (Figure 1A and discussed below) produced the expected 3.2 - and $3.5-\mathrm{kb}$ fragments in the wild type and putative ectopic transformant Tpac1-9.1 but failed to hybridize with DNA from any of the three putative gene-replacement strains (Tpac1-1.2, Tpac1-4.5, and Tpac1-7.2) (Fig. 1B). To confirm that the lack of hybridization seen with probe 1 was the result of an elimination of corresponding pacl sequences from the genome, a second probe, probe 2 (Fig. 1A and discussed below), was used for hybridization. This probe hybridized with the expected $3.5-\mathrm{kb}$ band in the wild type and the $3.5-\mathrm{kb}$ plus a $10-\mathrm{kb}$ band in the Tpac1-9.1 strain. This 10-kb band in Tpac1-9.1 is indicative of an ectopic integration of the pacl-hph sequences. This same probe hybridized to a single $6.5-\mathrm{kb}$ band in transformants Tpac1-1.2, Tpac1-4.5, and Tpac1-7.2. (Fig. 1B). This 6.5-kb XbaI-SpeI band is the size predicted as a result of a replace- 
ment of the 3.5-kb XbaI-SpeI wild-type band with the pac1$h p h$ fragment via a homologous, double-recombination event. A model of the pacl gene replacement consistent with the Southern hybridization data is diagrammed in Figure 1A. This gene-replacement event is predicted to result in loss of Pac1 function, and the loss-of-function allele is designated pacl-1.

In the 12 other independent transformants examined, two patterns of hybridization were observed (data not shown). Five of these transformants produced a hybridization pattern similar to Tpac1-9.1, consistent with ectopic integration of the vector sequences. Genomic DNA from the other seven transformants hybridized strongly with a $6.5-\mathrm{kb}$ band and weakly with a 3.5$\mathrm{kb}$ band. This pattern is indicative of heterokaryosis, in which wild-type and gene-replacement nuclei exist in a common cytoplasm.

Transformant Tpac1-7.2 was chosen as a representative pac1 gene-replacement strain and was utilized as a recipient for complementation, via transformation with pPKPacSBAR and pBARGEM7-1 vectors. The pPKPacSBAR vector contains the intact genomic pacl gene and the bar gene cassette conferring resistance to bialaphos. Bialaphos-resistant transformants were recovered, and one strain, Tpac1-4.1, was analyzed by Southern hybridization (Fig. 1B). In XbaI-SpeI double-digested genomic DNA from transformant Tpac1-4.1, probe 1 hybridized strongly with $3.2-$ and $8-\mathrm{kb}$ bands. This hybridization pattern is consistent with an ectopic integration of pPKPacSBAR. In this same transformant, probe 2 hybridized with an 8 -kb band only. Although consistent with an ectopic integration of intact pacl sequences, the absence of the $6.5-\mathrm{kb}$ band present in the Tpac1-7.2 recipient strain indicates that a rearrangement at the pacl site may have occurred. As a control for this complementation experiment, Tpac1-7.2 was also transformed with an empty bar-gene vector, pBARGEM7.1. XbaI-SpeI doubledigested genomic DNA from transformant Tpac1-2.2 failed to hybridize with probe 1 (Fig. 1B), hybridized with the $6.5-\mathrm{kb}$ band with probe 2 (Fig. 1B), and hybridized with a $1.2-\mathrm{kb}$ band with the bar sequence as a probe (data not shown). This pattern is consistent with genomic integration of pBARGEM7-1 vector sequences at a site ectopic of the disrupted pacl locus.

\section{pac1 is required for sclerotial development and for vegetative growth at elevated $\mathrm{pH}$.}

When grown on nonbuffered potato dextrose agar (PDA) medium, differences in mycelial growth were not evident among the wild type, the ectopic transformant (Tpac1-9.1), and the pac1 gene-replacement mutants (Tpac1-1.2, Tpac1-4.5, and Tpac1-7.2). Sclerotial development, however, was aberrant in the pacl gene-replacement mutants (Fig. 2). The timing and frequency of sclerotia initiation does not appear to be reduced, however; discrete sclerotial development with a delimiting melanized rind layer was absent. The ectopic strain Tpac1-9.1 did not exhibit aberrant sclerotial development. The pPKPacSBAR-complemented transformant Tpac1-4.1 was restored to wild-type sclerotial development, whereas sclerotial development in the pBARGEM7.1 control transformant
Tpac1-2.2 was indistinguishable from the progenitor Tpac1-7.2 strain (Fig. 2).

To determine if the pacl mutation affected growth in response to external $\mathrm{pH}$, radial growth of the wild type, the ectopic transformant, and the pacl gene-replacement mutant was examined over time on buffered PDA media. Radial growth of all three strains was equal at $\mathrm{pH} 3.5$ and 4.2 (Fig. 3A and B). At $\mathrm{pH} 5.2$, radial growth of the pacl gene-replacement mutant Tpac1-7.2 was obviously inhibited relative to the wild-type and ectopic strains (Fig. 3C). At pH 6.2, growth of all strains was inhibited relative to growth at lower $\mathrm{pH}$, and growth of the gene-replacement mutant was almost completely inhibited (Fig. 3D). All strains, including wild type, were unable to grow on PDA buffered at pH 7.5 (data not shown).

\section{Oxalate production is reduced \\ but remains pH-responsive in pac1 mutants.}

In S. sclerotiorum and many other oxalic acid-producing fungi, oxalic acid accumulation is promoted by alkaline $\mathrm{pH}$ growth conditions. The effect of the pacl gene replacement on oxalic acid accumulation kinetics was determined by quantifying oxalic acid accumulation over time from buffered $(\mathrm{pH} 3,5$, and 7) liquid cultures. In the wild-type and ectopic strains, oxalic acid accumulation was positively regulated by alkaline ambient $\mathrm{pH}$ (Fig. 4A and B). In cultures buffered at $\mathrm{pH} 7.0$, a 5-h lag in oxalic acid accumulation was followed by a steep increase that reached a plateau by $15 \mathrm{~h}$. Accumulation kinetics at pH 5 was more gradual and reached a plateau at a concentration that was approximately $75 \%$ lower than at $\mathrm{pH} 7$. Only basal levels of oxalic acid accumulated at pH 3 in the wildtype and ectopic strains. The pacl replacement mutant also exhibited alkali-responsive oxalate production; however, the kinetics and magnitude of accumulation were markedly altered (Fig. 4C). At pH 7, oxalic acid accumulation lagged nearly 15 $\mathrm{h}$, and then, accumulated gradually until the end of the experiment. Final oxalic acid accumulation at $\mathrm{pH} 7$ was more than $75 \%$ lower than wild-type accumulation. Basal levels of oxalic acid accumulated at $\mathrm{pH} 5$ and 3 in the pacl gene-replacement mutant.

\section{pac1 mutants exhibit derepressed endopolygalacturonase gene expression in response to alkaline ambient $\mathbf{p H}$.}

Much like the autogenously regulated $A$. nidulans pacC gene, the pacl gene is alkaline-expressed. Northern analysis of pac1 transcript accumulation in the wild-type and ectopic strains incubated over a range of $\mathrm{pH}$ conditions demonstrates its positive regulation in response to increasing alkalinity (Fig. $5 \mathrm{~A}$ and $\mathrm{B}$ ). In the pacl gene-replacement strain, hybridization with the full-length pacl cDNA probe was limited to a higher molecular weight band in the pH 5.8 to 7.0 lanes (Fig. 5A). A similarly sized band was observed in the RNAs from the wildtype and ectopic strains as well (Fig. 5A and data not shown). The functional relationship of this hybridizing band to the fulllength pacl transcript is not clear. The effective elimination of expression of sequences encoding the zinc finger DNA binding

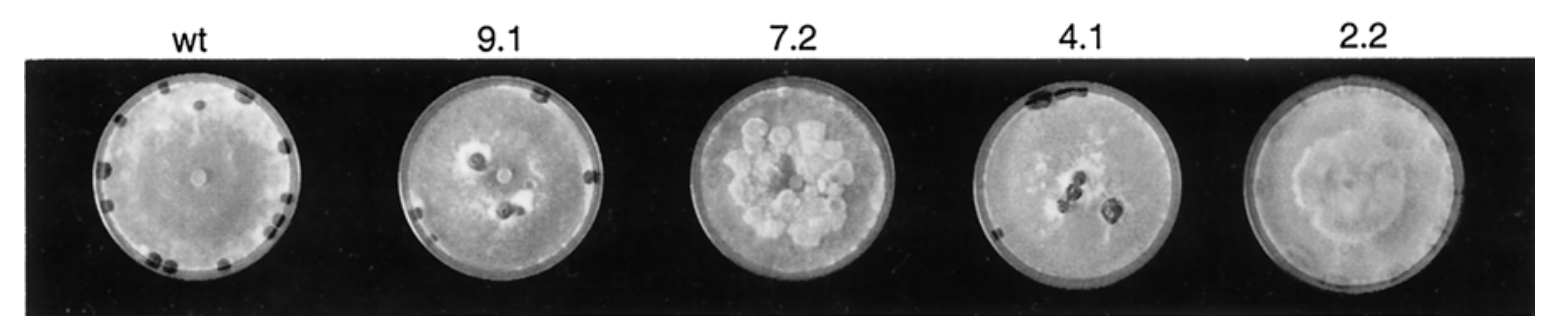

Fig. 2. Colony morphology of wild type (wt), ectopic Tpac1-9.1 (9.1), gene-replacement Tpac1-7.2 (7.2), pac1-complemented Tpac1-4.1 (4.1), and noncomplemented control strain Tpac1-2.2 (2.2) grown on potato dextrose agar medium for 12 days. 

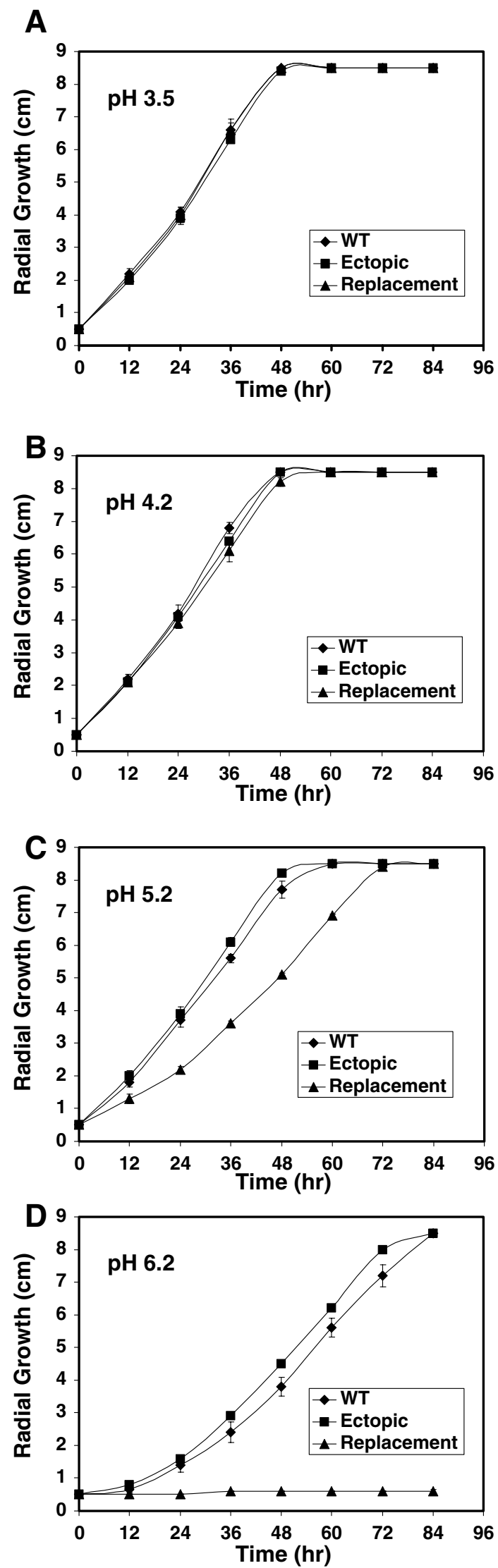

Fig. 3. Radial growth over time of wild type, ectopic strain Tpac1-9, and gene-replacement strain Tpac1-7.2 on citrate-phosphate-buffered potato dextrose agar. Media $\mathrm{pH}$ values at the time of inoculation were $\mathbf{A}, 3.5, \mathbf{B}$, 4.2, C, 5.2, and D, 6.2. Colony diameters were measured at 12-h intervals. Each point represents the mean colony diameter \pm the standard deviation from three independent colonies. domain in the gene-replacement strain was further demonstrated by a lack of Northern blot hybridization with a probe derived from the sequences targeted for deletion (probe 1 used for Southern hybridization analysis; data not shown). This lack of hybridization observed with this probe corroborated the Southern hybridization data indicating the gene-replacement strain is genetically pure, containing only the pacl-1 loss-offunction allele.

A

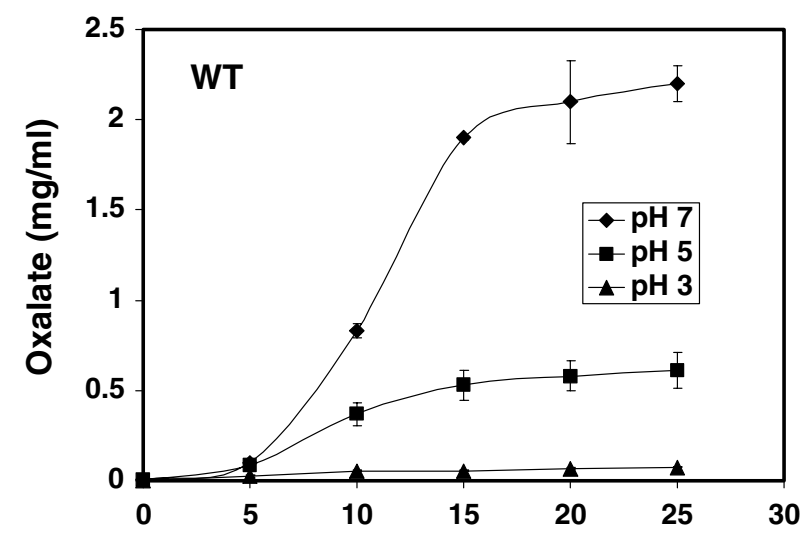

B
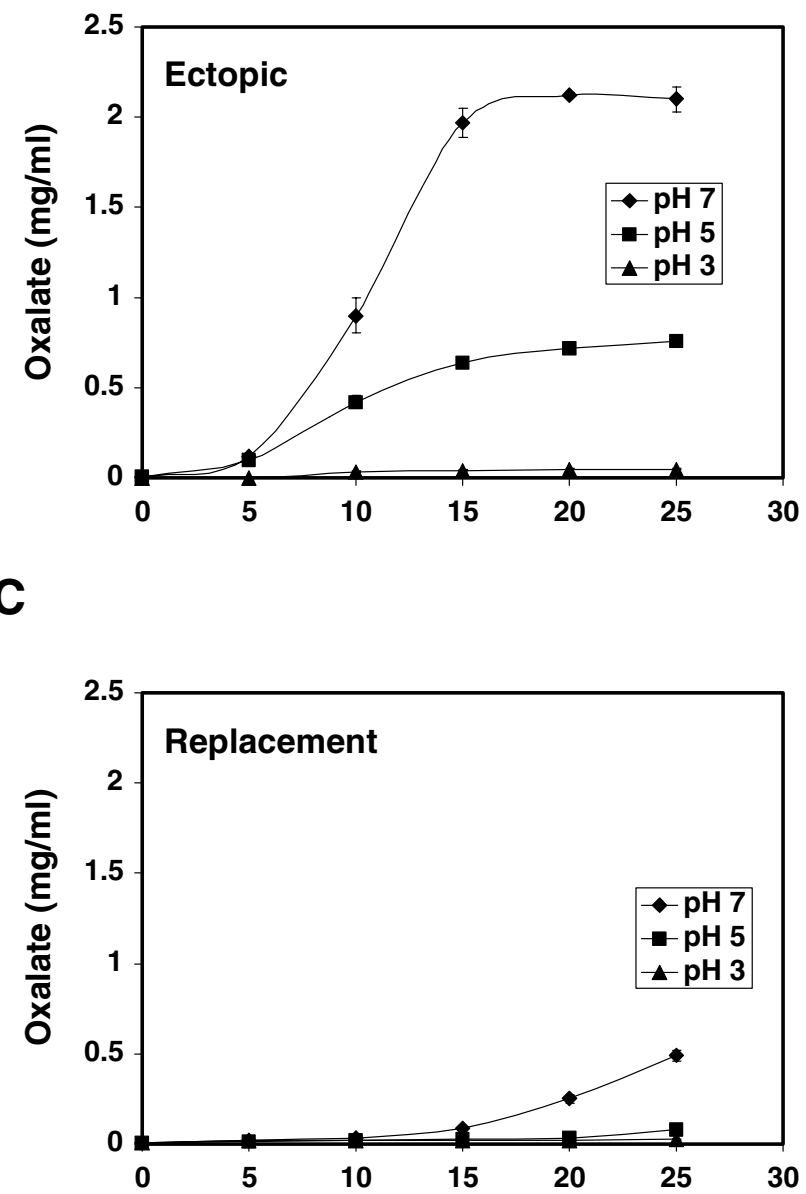

Fig. 4. Oxalic acid accumulation kinetics from $0.5 \mathrm{M}$ MOPS-buffered

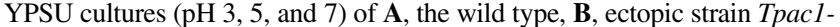
9.1, and C, gene-replacement strain Tpac1-7.2. Data points represent the mean and standard deviation from three independent cultures. 
In the wild type, accumulation of endopolygalacturonase pg1 transcripts is promoted by an acidic growth environment (Rollins and Dickman 2001). To determine the effect of the pacl loss-of-function mutation on in vitro $p g l$ transcript accumulation, levels of $p g l$ transcript were compared among wild type, ectopic, and gene-replacement pacl strains after $4 \mathrm{~h}$ of incubation at different ambient $\mathrm{pH}$ conditions. The wild type and the ectopic transformant (Tpac1-9.1) accumulated pgl maximally at or below pH 4.6 (Fig. 5A and B). pgl transcript accumulation was maximal above $\mathrm{pH} 4.6$ in the Tpac1-7.2 mutant (Fig. 5A). Unexpectedly, the level of $p g 1$ transcript accumulation below $\mathrm{pH} 4.2$ was dramatically less in this gene-replacement strain compared with that in the wild type (Fig. 5A). When transcript accumulation was quantified and normalized for equal loading by phosphorimaging (Fig. 5B), the results confirmed the observation that $\mathrm{pH}$ conditions above 4.6 no longer repressed pg1 transcript accumulation in the Tpac1-7.2 pacl gene-replacement strain. Quantitatively, the level of $p g 1$ transcript accumulation below $\mathrm{pH} 4.2$ in the pacl gene-replacement strain is similar to what is observed above $\mathrm{pH} 4.2$ in the wild type (Fig. 5B). The results from this Northern analysis demonstrate that pgl transcript accumulation in the loss-offunction Tpac1-7.2 strain has shifted from an acidic to a more basic $\mathrm{pH}$ optimum.

pac1 knockout mutants are reduced in virulence.

Infection assays on detached tomato leaflets and on Arabidopsis plants were performed to determine the effect of pacl loss-of-function on pathogenicity. Averaging across all Arabidopsis infection experiments, the mean percentage of leaves colonized per plant seven days postinoculation was $97.2 \% \pm$ $2.1 \%$ for the wild type, $95.8 \% \pm 2.5 \%$ for the ectopic strain (Tpac1-9.1), $27.5 \% \pm 8.1 \%$ for the gene-replacement strain (Tpac1-7.2), $89.2 \% \pm 5.2 \%$ for the complemented strain (Tpac1-4.1), $17.6 \% \pm 5.6 \%$ for the noncomplemented control strain (Tpac1-2.2), and 0\% for the mock inoculated control. One representative replicate of the Arabidopsis infection assays is shown in Figure 6A. Infection assays with these same strains were also performed on detached tomato leaflets. Four days after inoculation of tomato leaflets, the percentage of leaf area colonized, averaged across all experiments, was $90 \% \pm$ $11 \%$ for the wild type, $86 \% \pm 10 \%$ for the ectopic strain (Tpac1-9.1), $28 \% \pm 13 \%$ for the gene-replacement strain (Tpac1-7.2), 89\% $\pm 7 \%$ for the complemented strain (Tpac14.1 ), and $27 \% \pm 19 \%$ for the noncomplemented bar-transformed control strain (Tpac1-2.2). Representative results from one experiment are shown in Figure 6B.

\section{DISCUSSION}

\section{pac1 gene replacement.}

On the basis of its encoded amino acid sequence and ability to complement an A. nidulans null pacC mutant, the pacl gene from $S$. sclerotiorum was demonstrated previously to be a structural and functional homolog of the A. nidulans pac $C$ gene (Rollins and Dickman 2001). The goal of the present investiga-

A

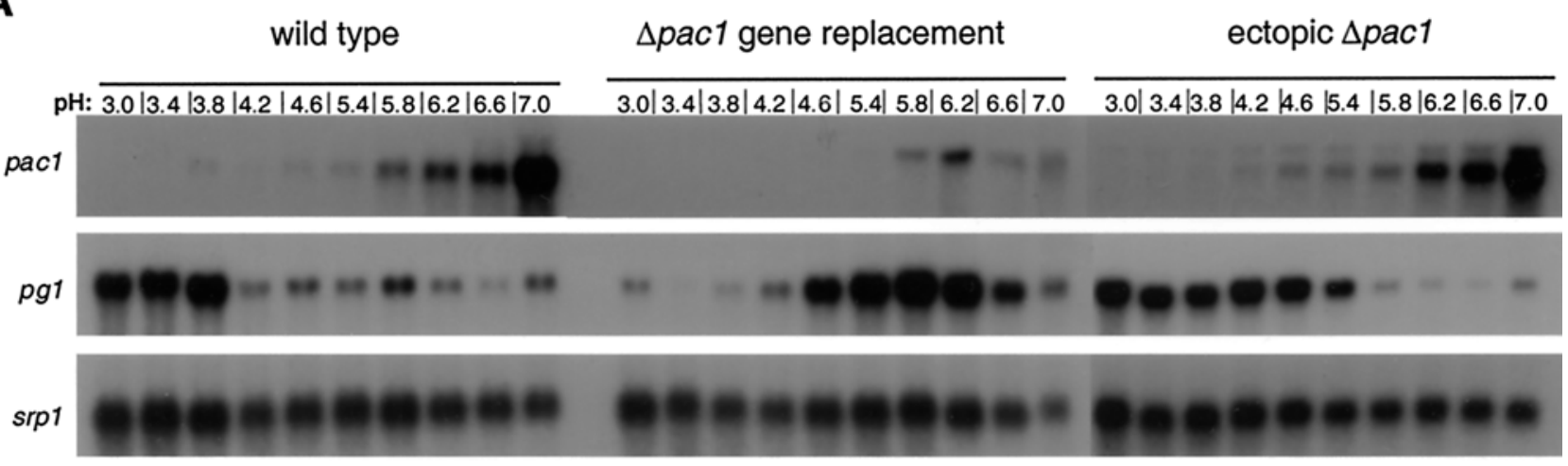

B

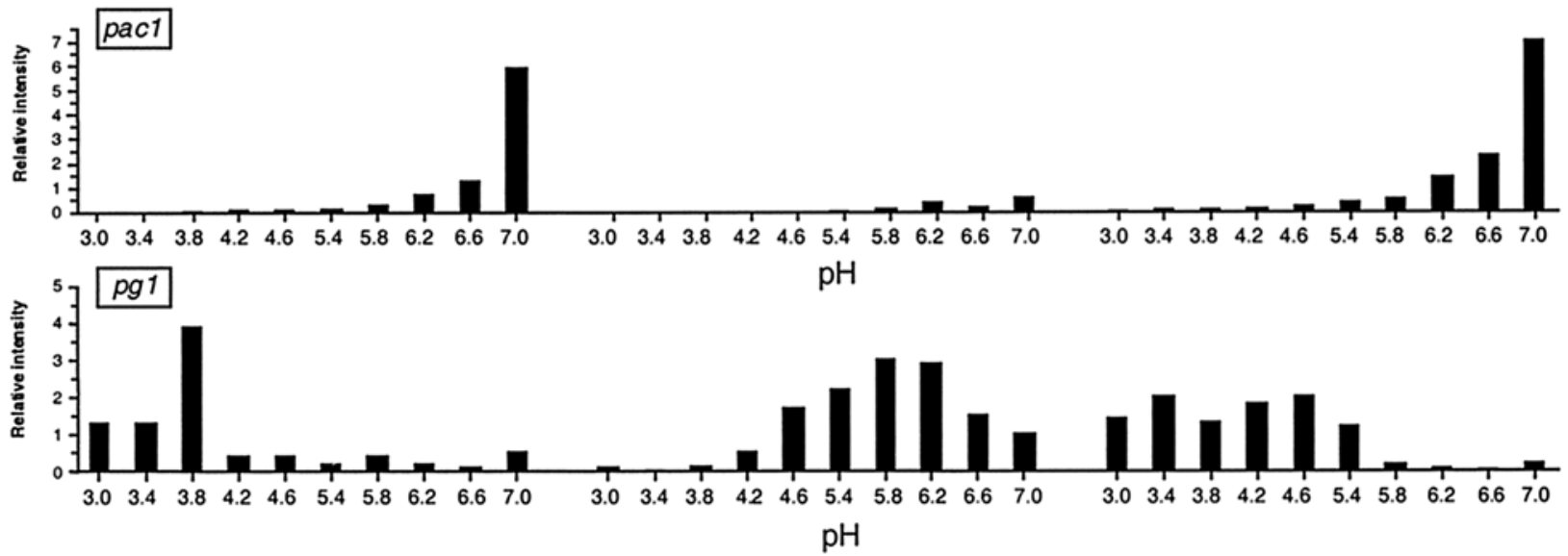

Fig. 5. Northern hybridization analysis of pacl and $p g 1$ transcript accumulation in wild-type and pacl strains. Mycelia from unbuffered YPSU liquid shake cultures were washed and aliquoted to citrate-phosphate-buffered YPSU media with the indicated initial $\mathrm{pH}$ values. Cultures were harvested after 4 $\mathrm{h}$ of incubation, and total RNA was extracted. A, RNA was fractionated by agarose gel electrophoresis transferred to nylon membrane, was hybridized with the indicated DNA probes, and was detected by autoradiography. The same subsequently stripped membrane was used for all hybridizations. B, pacl and $p g 1$ hybridization signals from the same blots shown in A were also detected by phosphorimaging and quantified relative to the srpl loading control. 
tion was to determine the functional consequences of pacl loss of function in S. sclerotiorum. This analysis has identified processes that are dependent on Pac1 function, including growth at neutral $\mathrm{pH}$, oxalic acid production, gene expression, and virulence. The attenuated virulence produced by this mutation has defined $\mathrm{pH}$-responsive gene expression as a significant molecular regulator of pathogenicity in this broad host range pathogen.

Three independent pacl loss-of-function mutants were isolated from $S$. sclerotiorum by targeted gene replacement. These mutants were initially identified from a pool of 75 independent transformants by visually screening cultures for aberrant sclerotial development and were subsequently confirmed by Southern hybridization to be monokaryotic pacl gene-replacement strains. A Southern hybridization screen of 12 additional wildtype-appearing transformants revealed five independent transformants with integration patterns consistent with ectopic integration of the pacl gene-replacement construct and seven transformants with integration patterns consistent with heterokaryotic mycelia consisting of wild-type nuclei and homologously integrated pacl gene-replacement nuclei. These numbers represent a high frequency of homologous integration events and unresolved heterokaryons. The lack of conidia precludes single-spore purification of heterokaryons with this fungus; however, hyphal-tip transfers were sufficient to produce several monokaryotic gene-replacement transformants. A higher frequency of genetic purification may be achieved through more rounds of hyphal-tip transfer, protoplasting, further selection for transformed nuclei, or a combination of these methods. This report is the first published account of genetic transformation and targeted gene inactivation in S. sclerotiorum. The high frequency of homologous integration suggests that homologous gene replacement could become a routine tool for functional gene analysis in S. sclerotiorum.

Several phenotypes associated with the pacl-1 loss-of function allele were fully complemented when the wild-type pacl allele was reintroduced via transformation. The most obvious phenotypic effect of pacl mutation was the in vitro development of coalesced immature sclerotia that failed to produce melanized outer rinds. A role for Pac1 in sclerotial development is not altogether surprising. Correlations between sclerotial development and oxalic acid production or acidification of the growth substrate have been made previously (Godoy et al. 1990; Rollins and Dickman 2001; Vega et al. 1970). Northern blots with RNA isolated from undifferentiated hyphae and from developing sclerotia of the wild type revealed that pacl transcripts accumulate specifically and to high levels in developing sclerotial tissue (data not shown). Our working hypothesis is that a low $\mathrm{pH}$ environment with little pacl transcription and protein activation is required for sclerotial initiation and that high levels of pacl transcription and functionally active Pac1 are required for mature sclerotial development. The observations that pacC mutants of $A$. nidulans exhibit abnormal morphology and reduced conidiation (Caddick et al. 1986; Tilburn et al. 1995) provide additional evidence that PacC homologs play a role in fungal development.

Decreased growth at elevated ambient $\mathrm{pH}$ was another phenotype exhibited by pacl loss-of-function mutants. Although the reported $\mathrm{pH}$ range for Sclerotinia growth is between $\mathrm{pH} 2$ and 10 (Tanrikut and Vaughan 1951), the determination of a $\mathrm{pH}$ growth optimum for $S$. sclerotiorum is complicated by its production of oxalic acid. This current study found that growth of the wild type is restricted at ambient $\mathrm{pH}$ values above $\mathrm{pH} 6$ and completely blocked above $\mathrm{pH}$ 7. Buffering capacity is obviously an important factor determining $\mathrm{pH}$ growth optimum. Substrates above $\mathrm{pH} 7$ would appear to be colonized only when accompanied by acidification via organic acid secretion. The neutral pH hypersensitivity of pacl mutants might be explained as an inability to produce sufficient oxalic acid to lower the ambient $\mathrm{pH}$ to a suitable level for growth. Since the wild type does not dramatically acidify $\mathrm{pH}$ 5-buffered media ahead of colonization (data not shown), the growth inhibition

A

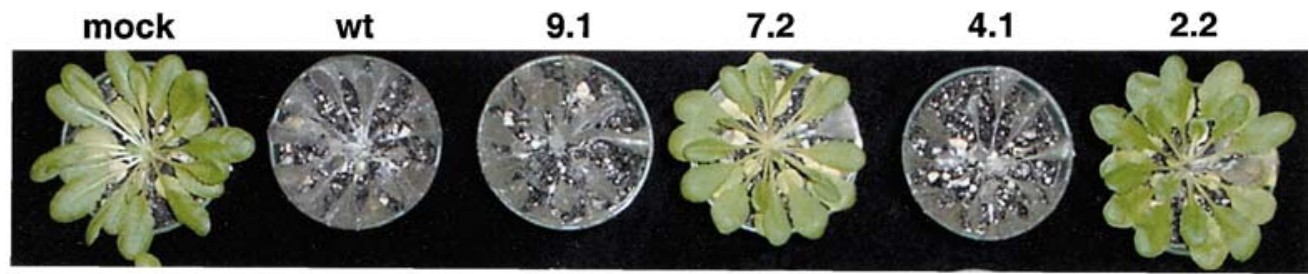

B

wt

9.1

7.2

4.1

2.2

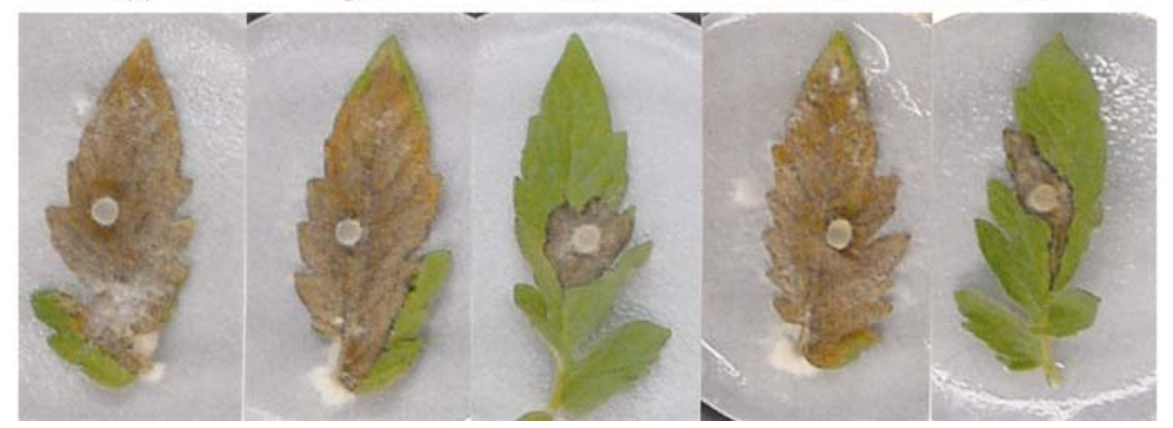

Fig. 6. Pathogenicity assays with wild-type and pacl strains. A, Arabidopsis plants (Co-1 ecotype) were mock inoculated with an uncolonized potato dextrose agar (PDA) plug (mock), inoculated with a PDA plug colonized with wild type (wt), ectopic strain Tpac1-9.1 (9.1), gene-replacement strain Tpac1-7.2, (7.2), pac1-complemented strain Tpac1-4.1 (4.1), or noncomplemented control strain Tpac1-2.2 (2.2). Photographs were taken 7 days postinoculation. One representative replication from one of four experiments is shown. B, Tomato leaflets (cv. Bonnie Best) were inoculated with PDAagar plugs colonized with the same strains shown in A. Percentage of area colonized was measured 4 days postinoculation. One representative replication from one of five experiments is shown. 
observed when the pacl replacement strain is grown at $\mathrm{pH} 5$ does not appear to be entirely attributed to an inability to rapidly acidify the environment. This observation, however, does not rule out the possibility that microenvironment acidification in the hyphal-growth zone occurs and is necessary. This growth inhibition may also be due to a more complicated defect in alkaline adaptation. This idea is supported by the observations that $A$. nidulans loss-of-function pacC mutants (Tilburn et al. 1995) and nonleaky pal $A, B, C, E$, and $F$ mutants (Caddick et al. 1986) are unable to grow at $\mathrm{pH}$ 8. Additionally, mutations in the $S$. cerevisiae RIM101 pathway result in decreased growth at high $\mathrm{pH}$ (Futai et al. 1999). A. nidulans and S. cerevisiae do not dramatically acidify their growth substrates in advance of colonization. These observations suggest that $S$. sclerotiorum pacl mutants may be deficient in other aspects of alkaline adaptation independent of oxalic acid secretion.

\section{pH-responsive gene regulation in $\mathbf{S}$. sclerotiorum.}

The role of $\mathrm{Pac} 1$ as a regulator of ambient $\mathrm{pH}$-responsive gene expression in S. sclerotiorum is supported by the observations that oxalic acid accumulation at $\mathrm{pH} 7$ is dramatically reduced and that pgl expression is derepressed under elevated $\mathrm{pH}$ conditions in the pacl loss-of-function mutant. However, two observations suggest that pgl expression and oxalate production in $S$. sclerotiorum are not prototypical $\mathrm{pH}$-regulated processes in accordance with the Pal-PacC ambient $\mathrm{pH}$ regulatory system (Peñalva and Arst 2002). First, oxalic acid accumulation, although greatly reduced, still accumulates preferentially at $\mathrm{pH} 7$ in the pacl mutant. Second, pgl transcript accumulation, which does exhibit expected alkaline derepression in the pacl loss-of function mutant, accumulates only marginally at $\mathrm{pH}$ values below 4.2. Based on the A. nidulans Pal-PacC model, high levels of $\mathrm{pg} 1$ accumulation independent of ambient $\mathrm{pH}$ are expected in a loss-of-function mutant. Although the pacl-1 loss-of-function allele does contain sequences encoding the $\mathrm{C}$-terminal 465 amino acids of Pac1, the possibility that these sequences are translated and perform a regulatory function is considered unlikely. First, these sequences are not expected to be transcribed in their normal context since the $5^{\prime}$ regulatory sequences for $\mathrm{PacC}$ binding are absent from pac1-1. Second, no hybridization with a full-length pacl probe was observed in Northern blots with the loss-of-function mutant at low $\mathrm{pH}$. The hybridization observed at high $\mathrm{pH}$ in this mutant is considered spurious but could represent illegitimate expression from the $h p h$ promoter. Accepting this possibility, however, still does not suggest a regulatory function at low $\mathrm{pH}$, as no accumulation of this transcript is observed at low $\mathrm{pH}$ and no regulatory function other than cis-regulation of the N-terminal residues has been determined for the $\mathrm{C}$-terminal residues of PacC (Peñalva and Arst 2002). To date, pgl is the only acid-expressed gene identified from $S$. sclerotiorum; therefore, we do not know if its behavior in the pacl loss-of-function mutant is a unique aspect of $p g l$ regulation or a general characteristic of acid-expressed genes from S. sclerotiorum. Decreased $\mathrm{pg} l$ transcript accumulation at low $\mathrm{pH}$ and continued $\mathrm{pH}$ responsiveness of oxalic acid accumulation may also be pleiotropic physiological effects relating to enzyme activities or $\mathrm{pH}$ homeostasis. The isolation and characterization of additional $\mathrm{pH}$-regulated genes from $\mathrm{S}$. sclerotiorum will provide a means to assess this and to determine whether Pac1 is a global and unique regulator of $\mathrm{pH}$-regulated genes in $S$. sclerotiorum. Current efforts are also underway to create and characterize dominant alkalinity-mimicking mutations in pacl. These mutants will provide a more complete understanding of the role Pac1 plays in regulating $\mathrm{pH}$-responsive processes in S. sclerotiorum.
Why is pac1 necessary for full virulence?

The full range of genes and processes regulated by Pac1 in $S$. sclerotiorum is unknown. The results of this study indicate that $\mathrm{Pac} 1$ is required for full $\mathrm{pH}$ induction of oxalic acid production and for the proper $\mathrm{pH}$-dependent regulation of endopolygalacturonase gene expression. The wealth of evidence linking the synergistic activities of oxalic acid and endopolygalacturonases with Sclerotinia pathogenesis (Marciano et al. 1983; Maxwell and Lumsden 1970) suggests that the observed reduction in virulence is the result of specific interference with these processes. The results do not provide a conclusive indication of whether the observed decrease in oxalic acid production is alone sufficient to account for the observed level of attenuated virulence. Reduced oxalic acid production during infection would decrease the rate of host tissue acidification. In turn, cell-wall-degrading enzyme activities might be reduced until sufficient oxalic acid accumulated. These effects alone may reduce the rate of lesion expansion. Other consequences of pacl mutation, however, cannot be discounted as playing significant roles in virulence. Although pgl transcript accumulation is increased at higher $\mathrm{pH}$ in the pacl mutant, transcript accumulation is reduced at low $\mathrm{pH}$ when enzyme activity would be maximal. The regulation of other cell-wall-degrading enzyme genes may likewise be altered by pacl mutation. The effect of pacl mutation on alkaline-adaptation is an additional factor that alone might account for the reduced rate of lesion expansion. This study strengthens the idea that oxalic acid production is of paramount importance for Sclerotinia pathogenicity but also expands the potential pathogenic roles of oxalic acid to include gene regulation. At the molecular level, a finetuned response to the dynamic $\mathrm{pH}$ environment involving both acid-specific and alkaline-specific gene expression appears to be important for full virulence.

\section{Global regulators of pathogenicity.}

Previous analyses of global, environment-responsive pathogenicity regulators have focused on signaling pathways and regulatory factors involved in carbon and nitrogen uptake and utilization. In Magnaporthe grisea, a loss of function mutation of the areA homolog NUT1 results in reduced in vitro production of an uncharacterized senescence factor (Talbot et al. 1997). However, this mutation has little effect on infection efficiency and lesion development on rice or barley (Froeliger and Carpenter 1996; Talbot et al. 1997). Two nonallelic genes, NPR1 and NPR2, involved in nitrogen source utilization independent of $N U T 1$, are also required for the production of the uncharacterized senescence factor (Talbot et al. 1997) and for expression of the pathogenicity-related hydrophobin gene MPG1 (Lau and Hamer 1996). Unlike mutations in NUT1, loss of function mutation in NPRI or NPR2 results in severely attenuated pathogenicity. The areA homolog from Cladosporium fulvum, Nrfl, is also dispensable for pathogenicity but required for significant in vitro production of the $A v r 9$ gene product (Pérez-García et al. 2001). The data from these studies suggest that global nitrogen regulatory genes can be important for the regulation of virulence factors and pathogenicity. However, several major regulatory factors and signaling pathways may control gene-specific responses to nitrogen.

The idea of carbon-nutrition regulation of pathogenicity has primarily focused on carbon-catabolite repression of cell-walldegrading enzymes (Gómez-Gómez et al. 2002; ReymondCotton et al. 1996; Tonukari et al 2000; Wubben et al. 2000). creA is a major carbon catabolite regulatory gene in filamentous fungi functionally homologous to MIG1 from yeast. This class of transcriptional regulators function in the presence of glucose to repress genes required for the uptake and catabolism of more complex carbon sources. In yeast, the derepression of carbon 
catabolite genes is positively regulated by the Snf1 protein kinase. In a study of Snf1 function in Cochliobolus carbonum, Tonukari and associates (2000) reported that functional inactivation of the $S N F 1$ gene resulted in a reduction in enzyme activity and transcript accumulation for numerous cell-wall-degrading enzymes. This mutation results in a dramatic decrease in lesion numbers. Thus, interference with the ability to properly sense and respond to the ambient carbon and nitrogen environments can attenuate virulence in phytopathogenic fungi.

Dynamic ambient $\mathrm{pH}$ environments are common during host-pathogen interactions. Several Colletotrichum species secrete ammonia during host infection in quantities significant enough to raise ambient $\mathrm{pH}$ and enhance pathogenicity (Prusky et al. 2001). In avocado fruit, increases in $\mathrm{pH}$ are associated with susceptibility to the avocado-infecting pathogen Colletotrichum gloeosporioides, which accumulates pectate lyase- and endopolygalacturonase-encoding transcripts as ambient $\mathrm{pH}$ is increased (Yakoby et al. 2000). In Alternaria alternata, expression of an endo-1,4- $\beta$-glucanase gene and decay of infected persimmon fruit was enhanced when $\mathrm{pH}$ was exogenously increased (Eshel et al. 2002). In Botrytis cinerea, another oxalic acid-producing phytopathogen, low $\mathrm{pH}$ was reported to increase the accumulation of endopolygalacturonase-encoding transcripts (Wubben et al. 2000). Reports of ambient $\mathrm{pH}$ playing a role in pathogenicity-associated gene expression are not limited to these few examples of phytopathogenic fungi. The entomopathogenic fungus Metarhizium anisopliae regulates transcripts for secreted proteolytic and chitinolytic enzymes in response to ambient $\mathrm{pH}$, such that the encoded enzymes are only produced in $\mathrm{pH}$ environments in which they effectively function (St. Leger et al. 1998). In the opportunistic human pathogen Candida albicans, transition from budding to infectious filamentous growth and accumulation of transcripts encoding virulence factors are regulated by ambient $\mathrm{pH}$ (Davis et al. 2000b). A direct role for the Candida albicans pacC homolog RIM101 during pathogenesis of animals was provided by the observation that rim101- $/ \mathrm{rim} 101^{-}$mutants displayed severe virulence defects in a murine model, failed to stimulate a strong immune response or develop microabscesses in kidneys, and caused only limited endothelial cell damage (Davis et al. 2000a). These reports clearly indicate that ambient $\mathrm{pH}$ plays a significant regulatory role in diverse host-pathogen interactions. In Sclerotinia, mediation of this signal is accomplished at least partially through Pac1. PacC orthologs may function as global regulators of pathogenicity in other host-pathogen interactions as well. This regulation may be particularly relevant in interactions with dramatic $\mathrm{pH}$ dynamics but may also be significant during interactions in which the ambient $\mathrm{pH}$ dynamics are more subtle, such as cell lysis during colonization or alkalization associated with oxidative burst.

\section{MATERIALS AND METHODS}

Fungal isolates, media, and growth conditions.

The wild-type 1980 isolate of S. sclerotiorum (Godoy et al. 1990) and strains derived from this isolate were used. Cultures were routinely grown on PDA (Difco, Detroit, MI, U.S.A.) and were propagated by mass hyphal transfer. Long-term storage stocks were maintained as desiccated mycelia-colonized filter paper and sclerotia at $-20^{\circ} \mathrm{C}$. Liquid shake cultures of mycelia were obtained by inoculating $50 \mathrm{ml}$ of YPSU medium (containing $4 \mathrm{~g}$ yeast extract per liter [Difco], $15 \mathrm{~g}$ sucrose, $1 \mathrm{~g}$ $\mathrm{K}_{2} \mathrm{HPO}_{4}$, and $0.5 \mathrm{~g} \mathrm{MgSO}_{4}, \mathrm{pH}$ 6.5) in a $125-\mathrm{ml}$ flask with eight approximately $2.5-\mathrm{mm}^{3}$ mycelial plugs from PDA cultures. Cultures were incubated at room temperature, shaking at $125 \mathrm{rpm}$ for 5 to 7 days, were blended with a hand mixer, and then, were harvested $24 \mathrm{~h}$ later.
General procedures for nucleic acid manipulations.

Lyophilized mycelia from liquid shake cultures of S. sclerotiorum were used to isolate total genomic DNA, using the method previously described by Yelton and associates (1984) for A. nidulans. Total RNA was isolated with Trizol reagent (Gibco BRL, Rockville, MD, U.S.A.), according to the manufacturer's instructions. RNA electrophoresis was conducted as previously described (Rollins and Dickman 2001). Plasmid DNA isolation, agarose gel electrophoresis, DNA restriction endonuclease and ligation reactions, and transformation of $E s$ cherichia coli were conducted using standard procedures (Sambrook and Russell 2001). E. coli strain DH5 $\alpha$ was used to propagate plasmids. After enzyme digestion and electrophoretic separation, genomic DNAs were transferred to MagnaGraph nylon membrane (Micron Separations Inc., Westborough, MA, U.S.A.) by downward alkaline transfer (Chomczynski 1992), and then UV-crosslinked. After denaturation and electrophoretic separation, RNAs were transferred to MagnaGraph nylon membrane by standard procedures (Ausubel et al. 1991). DNA and RNA hybridization analyses were conducted under high stringency conditions defined by Ausubel and associates (1991) and were analyzed by autoradiography. Northern blots were also scanned by a PhosphorImager (Molecular Dynamics, Sunnyvale, CA, U.S.A.). Hybridization signals were quantified using IMAGEQUANT software (Molecular Dynamics), and the reported relative level of signal in each lane was corrected, based on the hybridization signal from the srpl probe, described below. All pH-transfer experiments and Northern blots were repeated a minimum of three times.

\section{Construction of pac1 gene-replacement and complementation vectors.}

Plasmid vector pPKPacS (Rollins and Dickman 2001), containing the genomic pacl gene (GenBank accession number AY005467) and flanking sequences, was used as a template for the construction of a gene-replacement vector. pPKPacS was digested with SnaB1 to remove 1,612 base pairs spanning 996 base pairs upstream of the ATG start site of pacl, including all eight of the 5'-GCCAAG-3' PacC consensus binding sites, to 615 base pairs downstream of the ATG start site (codons 1 to 159), including all three of the zinc finger DNA-binding domains (codons 47 to 133). A hygromycin phophotransferase gene cassette $(h p h)$ contained on a 1.4-kb SalI fragment from pCB1004 (Carroll et al. 1994) was filled in with Klenow polymerase and was inserted via blunt-end ligation into the $\mathrm{SnaB} 1$ sites. This new vector, $\mathrm{p} \Delta \mathrm{Pac} 1$, contained the $1.4-\mathrm{kb}$ $h p h$ cassette in place of $1.6 \mathrm{~kb}$ of pacl coding and upstream sequences.

To create a plasmid for complementing pacl disruption strains, the pPKPacS vector was linearized with $\mathrm{XbaI}$ and was ligated to a 1.2-kb XbaI-SpeI fragment containing the bialaphos resistance-conferring bar gene cassette from pBARGEM7.1 (Pall and Brunelli 1993). This plasmid construct was designated pPKPacSBAR.

\section{Fungal transformation and evaluation of integration events.}

Protoplasts of the wild-type S. sclerotiorum 1980 strain were prepared essentially as described by Kohn and associates (1991), with the exception that cultures were grown in potato dextrose broth (Difco) and lysing enzyme (Sigma, St. Louis) or Murienase (USB, Cleveland, OH, U.S.A.) were substituted for NovoZym 234. Protoplasts were resuspended at a concentration of $1 \times 10^{8}$ protoplasts per $\mathrm{ml}$ in four parts STC (1.2 M sorbitol, $10 \mathrm{mM}$ Tris- $\mathrm{HCl}, \mathrm{pH} 7.5,10 \mathrm{mM}$ $\mathrm{CaCl}_{2}$ ) one part PEG (40\% polyethylene glycol $3350,50 \mathrm{mM}$ Tris-HCL, pH 7.5, $50 \mathrm{mM} \mathrm{CaCl}{ }_{2}$ ) solution, plus $1 \%$ dimethyl 
sulfoxide and $0.3 \mathrm{mg}$ of heparin per $\mathrm{ml}$. These protoplast stocks were routinely stored at $-80^{\circ} \mathrm{C}$. For fungal transformation, $5 \mu \mathrm{g}$ of DNA was mixed with $2 \mu \mathrm{l}$ spermidine $(50 \mathrm{mM}$ stock) and $5 \mu \mathrm{l}$ heparin (2.5 $\mathrm{mg}$ per $\mathrm{ml}$ in STC stock) and, then, immediately added to $100 \mu \mathrm{l}$ of the protoplast stock solution. This mixture was incubated on ice for $30 \mathrm{~min}$ and, then, gently mixed with $1 \mathrm{ml}$ of PEG solution and incubated at room temperature for $20 \mathrm{~min}$. Each suspension was evenly spread on the surface of $25 \mathrm{ml} \mathrm{RM} \mathrm{(239.6} \mathrm{g} \mathrm{of} \mathrm{sucrose,} 0.5 \mathrm{~g}$ of yeast extract per liter) bottom agar plates (15 g of agar per liter). Plates were incubated 15 to $18 \mathrm{~h}$ in the dark at room temperature, then overlaid with four $\mathrm{ml}$ of molten $\mathrm{RM}$ top agar (8 $\mathrm{g}$ of agar per liter) containing $2.9 \mathrm{mg}$ of hygromycin B. Colonies that regenerated through the top agar were transferred to PDA media containing $100 \mu \mathrm{g}$ of hygromycin per milliliter. Hygromycin-resistant transformants were hyphaltip transferred a minimum of three times on PDA containing $100 \mu \mathrm{g}$ of hygromycin per milliliter.

For gene-replacement experiments, $\mathrm{p} \Delta \mathrm{Pac} 1$ was double-digested with $X b a I$ and $X h o I$, releasing a $5.7-\mathrm{kb}$ fragment containing the $h p h$-disrupted pacl gene. This fragment was gelpurified with silica (GeneClean; Qbiogene, Carlsbad, CA, U.S.A.) and was introduced into the genome of wild-type $S$. sclerotiorum 1980 via PEG-mediated protoplast transformation. Southern hybridization was used to screen for transformants that integrated the pacl disruption construct through a double recombination event at the pacl locus. For this analysis, genomic DNAs of hygromycin B-resistant transformants were double-digested with $\mathrm{XbaI}$ and SpeI and were hybridized with probes 1 and 2 shown in Figure 1. Sequences for probe 1 were derived by PCR amplification of the pPKPacS template, using primers GPAC-F3 (5'-CTTCGGTTCATACTTGTATGG-3') and PACS-R4c (5'-GAATCATCGGCATGGGTC-3'). The 1.3-kb fragment represents nucleotides 355 to 1,635 of the pacl genomic sequence (GenBank accession number AY005467). These sequences are not present on the $\mathrm{p} \Delta \mathrm{Pac} 1$ disruption construct. Based on the sequencing and restriction enzyme mapping of genomic clones (Rollins and Dickman 2001), these probe sequences are predicted to hybridize with 3.2 - and $3.5-\mathrm{kb}$ fragments in XbaI-SpeIdigested wild-type DNA and predicted not to hybridize to any fragments in a pacl gene-replacement transformant. Sequences for probe 2 were derived by PCR amplification of the pPKPacS template using primers PACS-R1 (5'-GGATACAGACAACCAGGCGG-3') and PacsR2c (5'-CTTGAGTTAAGTCCACCAGC-3'). The 1.1-kb product of these primers represents nucleotides 1,689 to 2,755 of the pacl genomic sequence (GenBank accession number AY005467). These sequences are present on both the genomic pPKPacS plasmid and the $\mathrm{p} \Delta \mathrm{Pac} 1$ disruption construct. Hybridization with this sequence is predicted to produce a $3.5-\mathrm{kb}$ band in XbaI-SpeIdigested wild-type DNA and a $6.5-\mathrm{kb}$ band in an XbaI-SpeIdigested pac1 gene-replacement transformant. Sequences for hybridization were $\alpha{ }^{32} \mathrm{P}$-labeled with a random primers labeling system (Invitrogen Corp., Carlsbad, CA, U.S.A.). PCR reactions consisted of $3 \mathrm{~min}$ at $94^{\circ} \mathrm{C}, 30$ cycles of $1 \mathrm{~min}$ at $94^{\circ} \mathrm{C}, 1 \mathrm{~min}$ at $55^{\circ} \mathrm{C}$, and $1 \mathrm{~min}$ at $72^{\circ} \mathrm{C}$, followed by 7 min at $72^{\circ} \mathrm{C}$.

For complementation experiments, pacl gene-replacement strain Tpac1-7.2 was transformed as above with the pPKPacSBAR plasmid and selected on RM medium supplemented with $10 \mu \mathrm{g}$ of bialaphos per ml (Shinyo Sangyo Co., Tokyo).

\section{Assaying growth and oxalate production.}

Radial mycelial growth at $\mathrm{pH} 3.5,4.2,5.2,6.2$, and 7.5 was determined by measuring colony diameters of cultures grown on PDA buffered with citric acid-sodium phosphate buffer.
Plates were inoculated in the center of a 9-cm culture plate with an agar-mycelium plug obtained from the growing margin of a PDA culture. Measurements were taken at 12-h intervals until $84 \mathrm{~h}$ after inoculation. A minimum of three colony diameter measurements were made at each timepoint, and the largest diameter was recorded. Four replicates of each $\mathrm{pH}$ condition were conducted, and the experiment was repeated three times. The results from one representative experiment are shown.

To analyze the kinetics of oxalic acid accumulation in vitro, 500 -ml flasks containing $250 \mathrm{ml}$ of YPSU medium were inoculated with 16 approximately $2.5-\mathrm{mm}^{3}$ agar-mycelium plugs obtained from the advancing margin of PDA cultures. Cultures were shaken at $150 \mathrm{rpm}$ for 7 days at room temperature, were blended with a hand mixer and were returned to the shaker for $16 \mathrm{~h}$. Cultures were harvested by vacuum filtration onto filter paper and washed three times by resuspension in $600 \mathrm{ml}$ of sterile distilled water. Fresh mycelial mats were weighed, and $5 \mathrm{~g}$ of mycelia was resuspended in $250 \mathrm{ml}$ of sterile distilled water. Aliquots $(25-\mathrm{ml})$ of this washed mycelia were harvested by vacuum filtration, and the recovered mycelial mats (average wet weight, $500 \mathrm{mg}$ ) were resuspended in $50 \mathrm{ml}$ of fresh YPSU-MOPS media (YPSU buffered with $0.5 \mathrm{M} 3$ (N-morpholino-propane-sulfonic acid) with $\mathrm{pH}$ adjusted to 3.0, 5.0, or 7.0. Three replicates of each $\mathrm{pH}$ culture were established for each strain. Cultures were returned to shaking at room temperature and 500- $\mu \mathrm{l}$ samples of the media were taken immediately (time 0 ) and at 5-h intervals until $25 \mathrm{~h}$. Culture supernatants were analyzed for oxalic acid content with an enzymatic assay kit (Sigma), according to the manufacturer's instructions. Oxalic acid concentration was calculated by extrapolation from a standard curve. Values represent the mean and standard error of the mean of three replications. Growth and oxalate accumulation studies were repeated a minimum of three times, and data from one representative experiment are shown.

\section{Northern hybridization analysis.}

Primary cultures for Northern blot analysis were grown and harvested as described above for oxalate accumulation experiments. Hyphal mats (average fresh weight $500 \mathrm{mg}$ ) were incubated in fresh media with a range of $\mathrm{pH}$ values from 3.0 to 7.0. These 50-ml secondary cultures consisted of YPSU media buffered with citric acid-sodium phosphate buffer. Secondary cultures were incubated for $4 \mathrm{~h}$ at room temperature, shaking at $150 \mathrm{rpm}$, were harvested by vacuum filtration, were flash frozen in liquid nitrogen, and were lyophilized. Total RNA was extracted, electrophoretically separated, and transferred to nylon membranes, as described above. Blots were hybridized with a full-length pacl cDNA sequence ( $\operatorname{srpl}$ )representing nucleotides 861 to 3,444 minus intron sequences on the genomic pacl gene (GenBank accession number AY005467). Subsequently, blots were stripped and hybridized with the previously described pgl gene probe (Rollins and Dickman 2001) and a cDNA sequence encoding a $S$. sclerotiorum L-21 ribosomal protein homolog (GenBank accession number AY302590).

\section{Pathogenicity assays.}

Seeds of Arabidopsis thaliana accession Co-1 were germinated in sterile, medium coarseness Vergro vermiculite (Verlite Co., Tampa, FL, U.S.A.). Three week-old seedlings were transferred to individual $60-\mathrm{mm}$ diameter plastic pots containing Metro-Mix 300 potting soil (The Scotts Co., Marysville, $\mathrm{OH}, \mathrm{U} . \mathrm{S} . \mathrm{A}$.$) . Plants were cultivated an additional five$ weeks in a $20^{\circ} \mathrm{C}$ growth chamber with 16-h day and 8-h night cycle. Lighting was supplied by 15 -watt GE cool white fluorescent bulbs. Intact, nonflowering plants were inoculated in the center of the rosette with a 5-mm mycelia-colonized agar plug obtained from the expanding margins of PDA-grown 
colonies of the wild type and the pac1 strains grown on PDA supplemented with the appropriate selective agent. Uncolonized PDA plugs were used as inoculation controls. Inoculated plants were randomized and incubated at $100 \%$ relative humidity under the same growth chamber conditions used for growing the plants. At 7 days postinoculation, the number of healthy and necrotic leaves was counted on each plant. The percentage of diseased leaves per plant was used to quantify virulence. In each experiment, four plants were inoculated with each fungal strain, and the experiment was repeated five times. Results of one replicate from one representative experiment are shown.

Seeds of tomato (Lycopersicon esculentum Mill. cv. Bonny Best) were planted in Plugmix (W. R. Grace \& Co., Cambridge, MA, U.S.A.). After two weeks, the emerged seedlings were transferred to Metromix in $10-\mathrm{cm}$ plastic pots. Seedlings were grown for approximately five weeks in the greenhouse at temperatures ranging from $25^{\circ} \mathrm{C}$ (night) to $35^{\circ} \mathrm{C}$ (day). Individual, fully expanded leaflets were excised and placed in 9-cm glass dishes lined with water-saturated No. 1 Whatman filter paper. Individual leaflets were inoculated with a single 5-mm mycelia-colonized agar plug, obtained from the expanding margins of PDA-grown colonies of the wild type or the pac1 strains grown on PDA supplemented with the appropriate selective agent. Inoculated leaflets were maintained at $100 \%$ relative humidity at 18 to $22^{\circ} \mathrm{C}$ in the laboratory. Percentage of leaflet area colonized was determined four days after inoculation by digitally photographing the individual leaves, printing the images on a color ink jet printer, separating the symptomatic and asymptomatic regions of the images with scissors and weighing the individual pieces. In each experiment, three leaflets were inoculated with each fungal strain and the experiment was repeated four times. Results of one representative replicate from one experiment are shown.

\section{NOTE ADDED IN PROOF}

During the revision of this article, the functional characterization of a "pacC" ortholog was reported from Fusarium oxysporum (Caracuel, Z., Roncero, M., Espeso, E., GonzálezVerdejo, Garciá-Maceira, F., and DiPietro, A. 2003. The pH signalling transcription factor PacC controls virulence in the plant pathogen Fusarium oxysporum. Mol. Microbiol. 48:765779). This paper reports that in tomato root infection assays, a small increase in virulence was observed with loss-of-function pacC mutants, and severely attenuated virulence was observed with dominant activating pacC mutants.

\section{ACKNOWLEDGMENTS}

I thank U. Benny for her technical assistance during the course of this work and J. Jones, W. Jurick II, and D. Pring for comments on this manuscript. I thank J. Jones for providing the tomato seedlings used for infection assays. This research was supported by the Florida Agricultural Experiment Station and by BARD grant 3363-02 from the United StatesIsrael Binational Agricultural Research and Development Fund and approved for publication as Journal Series No.R-09532.

\section{LITERATURE CITED}

Arst, H. N., Jr., Bignell, E., and Tilburn, J. 1994. Two new genes involved in signalling ambient $\mathrm{pH}$ in Aspergillus nidulans. Mol. Gen. Genet. 245:787-790.

Ausubel, F. M., Brent, R., Kingston, R. E., Moore, D. D., Seidman, J. G., Smith, J. A., and Struhl, K. 1991. Current Protocols in Molecular Biology. John Wiley and Sons, New York.

Bateman, D. F. 1964. An induced mechanism of tissue resistance to polygalacturonase in Rhizoctonia-infected hypocotyls of bean. Phytopathology 54:438-445.
Bateman, D. F., and Beer, S. V. 1965. Simultaneous production and synergistic action of oxalic acid and polygalacturonase during pathogenesis by Sclerotium rolfsii. Phytopathology 58:204-211.

Boland, G. J., and Hall, R. 1994. Index of plant hosts of Sclerotinia sclerotiorum. Can. J. Plant Pathol. 16:93-108.

Caddick, M. X., Brownlee A. G., and Arst, H. N., Jr. 1986. Regulation of gene expression by $\mathrm{pH}$ of the growth medium in Aspergillus nidulans. Mol. Gen. Genet. 203:346-353.

Carpita, N. C., and Gibeaut, D. M. 1993. Structural models of primary cell walls in flowering plants: Consistency of molecular structure with the physical properties of the wall during growth. Plant J. 3:1-30.

Carroll, A. N., Sweigard, J. A., and Valent, B. 1994. Improved vectors for selecting resistance to hygromycin. Fungal Genet. Newsl. 41:22.

Chomczynski, P. 1992. One-hour downward alkaline capillary transfer for blotting of DNA and RNA. Anal. Biochem. 201:134-139.

Davis, D., Edwards, J. E., Jr., Mitchell, A. P., and Ibrahim, A. S. 2000a. Candida albicans RIM101 pH response pathway is required for hostpathogen interactions. Infect. Immun. 68:5953-5959.

Davis, D., Wilson, R. B., and Mitchell, A. P. 2000b. RIM101-dependent and -independent pathways govern $\mathrm{pH}$ responses in Candida albicans. Mol. Cell. Biol., 20:971-978.

Eshel, D., Miyara, I., Ailing, T., Dinoor, A., and Prusky, D. 2002. pH regulates endopolyglucanase expression and virulence of Alternaria alternata in persimmon fruit. Mol. Plant-Microbe Interact. 15:774-779.

Espeso, E. A., Tilburn, J., Arst, H. N., Jr., and Peñalva M. A. 1993. pH regulation is a major determinant in expression of a fungal penicillin biosynthetic gene. EMBO (Eur. Mol. Biol. Organ.) J. 12:3947-3956.

Espeso E. A., Tilburn, J., Sánchez-Pulido, L., Brown, C. V., Valencia, A., Arst, H. N., Jr., and Peñalva, M. A. 1997. Specific recognition by the Aspergillus nidulans three zinc-finger transcription factor PacC. J. Mol. Biol. 274:466-480.

Froeliger, E. H., and Carpenter, B. E. 1996. NUT1, a major nitrogen regulatory gene in Magnaporthe grisea, is dispensable for pathogenicity. Mol. Gen. Genet. 251:647-656.

Futai, E., Maeda, T., Sorimachi, H., Kitamoto, K., Ishiura, S., and Suzuki, K. 1999. The protease activity of a calpain-like cysteine protease in Saccharomyces cerevisiaeis required for alkaline adaptation and sporulation. Mol. Gen. Genet. 260:559-568.

Godoy, G., J. R. Steadman, J. R., Dickman, M. B., and Dam, R. 1990. Use of mutants to demonstrate the role of oxalic acid in pathogenicity of Sclerotinia sclerotiorum on Phaseolus vulgaris. Physiol. Mol. Plant. Pathol. 37:179-191.

Gómez-Gómez, E., Ruíz-Roldán, M. C., Di Pietro, A., Roncero, M. I. G., and Hera, C. 2002. Role in pathogenesis of two Endo- $\beta-1,4$-xylanase gene from the vascular wilt fungus Fusarium oxysporum. Fungal Genet. Biol. 35:213-222.

Kohn, L. M., Stasovski, E., Carbone, I., Royer, J., and Anderson, J. B. 1991. Mycelial incompatibility and molecular markers identify genetic variability in field populations of Sclerotinia sclerotiorum. Phytopathology 81:480-485.

Lambert, M., Blanchin-Roland, S., Le Louedec, F., Lépingle, A., and Gaillardin, C. 1997. Genetic analysis of regulatory mutants affecting synthesis of extracellular proteinases in the yeast Yarrowia lipolytica: Identification of a RIM101/pacC homolog. Mol. Cell. Biol. 17:3966-3976.

Lau, G., and Hamer, J. E. 1996. Regulatory gene controlling MPG1 expression and pathogenicity in the rice blast fungus Magnaporthe grisea. Plant Cell. 8:771-781.

Lumsden, R. D. 1970. Phosphotidase of Sclerotinia sclerotiorum produced in culture and in infected bean. Phytopathology 60:1106-1110.

MacCabe, A. P., van den Hombergh, J. P. T. W. Tilburn, J., Arst., H. N., Jr., and Visser, J. 1996. Identification, cloning and analysis of the Aspergillus niger gene pacC, a wide domain regulatory gene responsive to ambient pH. Mol. Gen. Genet. 250:367-374.

Magro, P., Marciano, P., and Di Lenna, P. 1984. Oxalic acid production and its role in pathogenesis of Sclerotinia sclerotiorum. FEMS (Fed. Eur. Microbiol. Soc.) Lett. 24:9-12.

Marciano, P., Di Lenna, P., and Magro, P. 1983. Oxalic acid, cell wall-degrading enzymes and $\mathrm{pH}$ in pathogenesis and their significance in the virulence of two Sclerotinia sclerotiorum isolates on sunflower. Physiol. Plant Pathol. 22:339-345.

Maxwell, D. P., and Lumsden, R. D. 1970. Oxalic acid production by Sclerotinia sclerotiorum in infected bean and in culture. Phytopathology 60:1395-1398.

Negrete-Urtasun S., Reiter, W., Diez, E., Denison, S. H., Tilburn, J., Espeso, E. A., Peñalva, M. A., and Arst., H. N., Jr. 1999. Ambient pH signal transduction in Aspergillus: Completion of gene characterization. Mol. Microbiol. 33:994-1003.

Pall, M. L., and Brunelli, J. P. 1993. A series of six compact fungal transformation vectors containing polylinkers with multiple unique restriction sites. Fungal Genet. News1. 40:59-62 
Peñalva, M. A., and Arst, H. N., Jr. 2002. Regulation of gene expression by ambient $\mathrm{pH}$ in filamentous fungi and yeasts. Microbiol. Mol. Biol. Rev. 66:426-446.

Pérez-García, A., Snoeijers, S. S., Joosten, M. H. A. J., Goosen, T., and De Wit, P. J. G. M. 2001. Expression of the avirulence gene Avr9 of the fungal tomato pathogen Cladosporium fulvum is regulated by the global nitrogen response factor NRF1. Mol. Plant-Microbe Interact. 14:316-325.

Prusky, D., McEveoy, J. L., Leverentz, B., and Conway, W. S. 2001. Local modulation of host $\mathrm{pH}$ by Colletotrichum spieces as a mechanism to increase virulence. Mol. Plant-Microbe Interact. 14:11051113.

Reymond-Cotton, P., Fraissinet-Tachet, L., and Fèvre, M. 1996. Expression of the Sclerotinia sclerotiorum polygalacturonase $p g 1$ gene: Possible involvement of CREA in glucose catabolite repression. 1996 Curr. Genet. 30:240-245.

Rollins, J. A., and Dickman, M. B. 2001. pH signaling in Sclerotinia sclerotiorum: Identification of a pacC/RIM1 homolog. Appl. Environ. Microbiol. 67:75-81

Sambrook, J., and Russell, D. W. 2001. Molecular cloning: A laboratory Manual. Cold Spring Harbor Laboratory, Cold Spring Harbor, NY, U.S.A.

Schmitt, E. K., Kempken, R, and Kück, U. 2001. Functional analysis of promoter sequences of cephalosporin $\mathrm{C}$ biosynthesis genes from Acremonium chrysogenum: Specific DNA-protein interactions and characterization of the transcription factor PACC. Mol. Genet. Gen. 265:508-518.

Shah, A. J., Tilburn, J., Adlard, M. W., and Arst, H. N., Jr. 1991. pH regulation of penicillin production in Aspergillus nidulans. FEMS (Fed. Eur. Microbiol. Soc.) Lett. 77:209-212.

St. Leger, R. A., Joshi, L., and Roberts, D. 1998. Ambient pH is a major determinant in the expression of cuticle-degrading enzymes and hydrophobin by Metarhiziyum anisopliae. Appl. Environ. Microbiol. 64:709-713.

Su, S. S. Y., and Mitchell, A. 1993. Molecular characterization of the yeast meiotic regulatory gene RIM1. Nucleic Acids Res. 21:3789-3797.
Suárez, T., and Peñalva, M. A. 1996. Characterization of a Penicillium chrysogenum gene encoding a PacC transcription factor and its binding sites in the divergent $p c b A B-p c b C$ promoter of the penicillin biosynthetic cluster. 1996. Mol. Microbiol. 20:529-540.

Talbot, N. J., McCafferty, H. R. K., Ma, M., Moore, K., and Hamer, J. E. 1997. Nitrogen starvation of the rice blast fungus Magnaporthe grisea may act as an environmental cue for disease symptom expression. Physiol. Mol. Plant Pathol. 50:179-195.

Tanrikut, S., and Vaughan, E. K. 1951. Studies on the physiology of Sclerotinia sclerotiorum. Phytopathology 41:1099-1103.

Tilburn, J., Sarkar, S., Widdick, D. A., Espeso, E. A., Orejas, M. Mungroo, J., Peñalva, M. A., and Arst, H. N., Jr. 1995. The Aspergillus PacC zinc finger transcription factor mediates regulation of both acidic- and alkaline-expressed genes by ambient pH. EMBO (Eur. Mol. Biol. Organ.) J. 14:779-790.

Tonukari, N. J., Scott-Craig, J. S., and Walton, J. D. 2000. The Cochliobolus carbonum SNF1 gene is required for cell wall-degrading enzyme expression and virulence on maize. Plant Cell 12:237-247.

Vega, R. R., Corsini, D., and Le Tourneau, D. 1970. Nonvolatile organic acids produced by Sclerotinia sclerotiorum in synthetic liquid media Mycologia 62:332-338.

Wilson, R. B., Davis, D., and Mitchell, A. P. 1999. Rapid hypothesis testing with Candida albicans through gene disruption with short homology regions. J. Bacteriol. 181:1868-1874.

Wubben, J. P., ten Have, A., van Kan, J. A. L., and Visser, J. 2000. Regulation of endopolygalacturonase gene expression in Botrytis cinerea by galacturonic acid, ambient $\mathrm{pH}$ and carbon catabolite repression. Curr. Genet. 37:152-157.

Yakoby, N., Kobiler, I., Dinoor, A., and Prusky, D. 2000. pH regulation of pectate lyase secretion modulates the attack of Colletotrichum gloeosporioides on avocado fruits. Appl. Environ. Microbiol. 66:1026-1030.

Yelton, M. A., Hamer, J. E., and Timberlake, W. E.. 1984. Transformation of Aspergillus nidulans by using a $\operatorname{trp} C$ plasmid. Proc. Natl. Acad. Sci. U.S.A. 81:1470-1474. 